\title{
Research on Practical training Strategy of Applied Accounting Talents in Independent Colleges
}

\author{
Hong Ji*1,a, Yunqin Zou ${ }^{2, b}$ \\ ${ }^{1}$ JiangXi NormalUniversity Science and TechnologyCollege, P.R. China, 330027 \\ ${ }^{2}$ JiangXiNormal University Education College, P.R. China, 330022 \\ ajxsdjh@vip.sina.com,b707477684@qq.com
}

\begin{abstract}
Key words: Independent college, application, accounting, practice.
Abstract.With the continuous development of China's market economy, the talent market demand for accounting professionals is increasing, the requirements are also getting higher and higher, but the overall situation of the accounting professionals graduating from college has been not optimistic. Independent college as a platform for the application of talent training, only to constantly improve the practice of accounting personnel in the operational level, in order to make it in the increasingly fierce competition in the education of sustainable and healthy development. The independent college practice of accounting talent training based on the necessity of in scientific inquiry, revealing the culture independent school of Applied Talents in accounting practice, the existing problems and restricting factors, and proposes some corresponding strategies from the perfect practical teaching material and so on.
\end{abstract}

\section{Introduction}

Independent college graduates of accounting theory, but the lack of practical ability, it is difficult to quickly enter the state of the accounting profession. Therefore, independent colleges attach importance to applied talents in accounting practice training equivalent to seize the key to the requirements of accounting professional and optimization of independent colleges accounting personnel training practice education system can not only conveying a large number of outstanding talents in the accounting for the society, but also can promote the influence of independent college.

\section{Existing problems in practical training of Applied Accounting Talents in Independent Colleges}

\subsection{Training target fuzzy}

On the one hand, although the independent college in accounting talents training goal of positioning is "Applied Accounting Talents", but a lot of independent college did not consider differences in independent college students and ordinary college students, the training objectives and ordinary undergraduate course is same, is still the senior accounting personnel training, this with the right training runs counter to the original intention. On the other hand, although some of the independent college attaches great importance to the cultivation of Applied Talents in accounting, but due to excessive attachment to the mother, to lack their own teachers, most of the teachers or maternal and sharing, differences and the teachers in the teaching process with little consideration given to the students, for students' independent and the parent students teaching without distinction, in Independent Colleges of applied accounting talents training ability not equal to one's ambition.

\subsection{Light management of teaching content}

Accounting is based on money as the main unit of measurement, the use of special methods to reflect and supervise the economic activities of a unit of an economic management work, belonging to the management disciplines. At present the majority of independent college accounting professional backbone of the professional courses summary for the basic accounting, intermediate financial accounting, cost accounting, management accounting, auditing, advanced financial accounting, the teaching emphasis on accounting, ignoring the teaching management. This is not in 
line with the needs of the modern market economy for the application of accounting personnel, but also does not meet the Independent Institute of applied accounting personnel training and positioning.

\subsection{The absence of practice teaching}

In practice, the rapid development of information technology, computer accounting system to gradually replace the manual accounting system. A qualified accountant in a new era should be skilled in accounting. And most of the independent colleges to open the "accounting basis" course content is too old, mainly to introduce the basic principle of manual accounting bookkeeping, rarely involved in the fundamental principles of accounting computerization, and the accounting electrical calculate "opened in the independent college's situation is not optimistic, the curriculum in the high part of the independent college to introduce how to realize the accounting information system, rarely give students practical operation of the opportunity. Even some of the independent college did not offer the "accounting" course, just in the student in accounting exam before training. Due to the restriction of various factors, independent college difficult for accounting students assigned to the practice of enterprise, so a lot of independent college is not unified arrange student internships, professional accounting lack of evaluation standard system of practice, the practice of supervision is not enough, learning process becomes a mere formality.

\section{Restrictive factors of the practical training of accounting talents in Independent Colleges}

\subsection{Practical condition}

On the one hand, most of the independent college practice teaching software and hardware facilities are very lack of. Many colleges and universities have not yet established a standardized accounting simulation laboratory, accounting practice, the practice of the information to the students, students like to do exercises in the classroom to complete. This approach due to the lack of simulation environment and the corresponding practice equipment and goods, students can't understand the connections between each link in the accounting work, are also unable to realize specialization and cooperation relationship between the various departments, is not conducive to the cultivation of their professional judgment. On the other hand, with the expansion of college enrollment, the number of students has increased significantly, a lot of independent colleges and universities accounting practice teaching needs of the site and the software can not be guaranteed.

\subsection{Allocation of Teachers}

On the one hand, the lack of teaching experience in Independent Colleges and the accounting business experience are all prepared by the teachers. Parent teacher teaching experience is relatively abundant, but due to in the teaching process with little regard to the differences between the students of independent college and its parent, no teaching methods for independent college students; and independent college teachers younger, mostly lack of practical operation. On the other hand. At present the accounting teachers in universities are mostly from school to school, the lack of practical experience and most colleges and universities didn't teachers to participate in social practice into teaching management plan or the formation of the system, teachers from the practice of phenomenon appear inevitably.

\subsection{Practice base}

On the one hand, it is difficult to find the accounting practice base. As a result of the accounting student population many, the fund and the teacher is limited, causes the accounting graduation practice to use the student to carry on the way which oneself carries on, lacks the essential regulation. On the other hand, graduates in accounting practice, and guide the accounting practice of personnel due to concerns about the accounting treatment of errors and do not want to let students practice, students in the internship units is difficult to come into contact with the original vouchers and accounting data, and practice "just not dry" phenomenon exists generally, resulting in 
students on the campus of accounting practice lose interest and student actual operation ability training, ineffective practice.

\subsection{Practice teaching material}

The quality of teaching materials is an important factor affecting the practice effect. There are two sources of practical teaching materials: first, the compilation of textbooks, the two is a ready-made textbook. Self compiled teaching materials according to the professional training objectives tailored, targeted, but also easy to update, but the school quality and writing ability. On the market a wide range of existing accounting practice and the variety of teaching material, but there are many shoddy, are the contents of the old data are provided is not complete, before and after the data inconsistency problems. These teaching materials not only guide the poor, but also bring a lot of trouble to practice.

\section{The optimization strategy of the practical training of accounting talents in Independent Colleges}

\subsection{Improve practice teaching conditions}

On the one hand, schools should increase the curriculum practice, let students go deep into the realities of life, understand the real accounting industry, linking theory with practice to apply what they have learned, in the actual operation process improve their practical ability. On the other hand, the founder and manager of independent colleges should pay more attention to the practice teaching of college, absorb the social funds, utilize all available resources and improve the teaching environment of the students. A qualified college as far as possible in the school set up in a professional laboratory, to ensure that students can learn the theory of knowledge in real time in the use of experimental practice, to test their own learning outcomes.

\subsection{Strengthening the construction of teaching staff}

Accounting practice teaching to guide the teacher's demand is higher, not only have a solid theoretical knowledge, but also have a wealth of practical experience, it is necessary to strengthen the construction of accounting practice teaching staff. On the one hand, the independent colleges should introduce the "double teacher" teachers. "Double qualification" teachers have both theoretical and practical qualities, so teachers can serve as a guide to the practice of teachers, to provide a strong guarantee for the training of accounting personnel. On the other hand, accounting is a professional needs of lifelong learning, independent college in support of the teachers in doing a good job of teaching at the same time, also want to encourage teachers through learning examination, to upgrade their qualifications and titles and guide them to establish the concept of lifelong learning. Independent colleges should create favorable conditions for teachers to participate in social practice, to improve their practical work experience. At the same time, independent colleges can also be trained to improve teachers' practical ability through the training of senior accountants, certified public accountants and so on.

\subsection{Strengthening the construction of practice base}

On the one hand, to strengthen the construction of internal and external practice training base, increase financial input in the accounting professional practice teaching base, to ensure that students practice teaching base for practice funds, the independent college to do make full use of social resources of education and for the community to provide the corresponding service is organic and unified. On the other hand, the independent colleges should pay attention to the construction of the training base in the school. Can be purchased by the school related software and hardware equipment, simulation of the practice of teaching the scene. Can also be from the practice factory or professional company to the school to establish a practice base, such an internship base can be introduced at the same time the latest technical information, the role of significant. 


\subsection{Improve practical teaching materials}

Strengthen the independent college accounting professional practice teaching material construction. One is in the content selection, according to the independent college accounting training objectives, highlighting the independent college characteristics and level requirements. Two is to shorten the time to revise the teaching material, follow the changes of the actual business and accounting system and standards, to meet the needs of the internship.

\section{References}

[1] XU Pingcai, YE Chenyi, WEI wei. The facing problems and countermeasures in Colleges and universities of our country accounting practice teaching [J]. Financial accounting, 2010 (10): 168-170.

[2] WENYouyun. Accounting talents in independent college culture revelation based on Guangzhou City private enterprises accounting recruitment intention analysis [J]. Chifeng University Journal, 2016 (4). Proceedings of the: 138-140.

[3] CHENLixin. [J]. China management informationization training mode innovation of accounting informatization talents in independent colleges, 2015 (1): 51-53.

[4] ZHANGYongli. Cultivation of practical accounting talents' practical ability [J]. Journal of Heilongjiang College of education, 2013 (12): 24-25.

[5] LIU Jun. On the target orientation of the accounting professional personnel training in Independent Colleges under the new situation [J].Journal of Lanzhou Institute of Education, 2013 (4): 65-68. 